\title{
Effects of elevated water temperature and food availability on the reproductive performance of a coral reef fish
}

\author{
J. M. Donelson ${ }^{1,2, *}$, P. L. Munday ${ }^{1,2}$, M. I. McCormick ${ }^{1,2}$, N. W. Pankhurst ${ }^{3}$, \\ P. M. Pankhurst ${ }^{3}$ \\ ${ }^{1}$ ARC Centre of Excellence for Coral Reef Studies, James Cook University, Townsville, Queensland 4811, Australia \\ ${ }^{2}$ School of Marine and Tropical Biology, James Cook University, Townsville, Queensland 4811, Australia \\ ${ }^{3}$ Australian Rivers Institute, Griffith University, Gold Coast Campus, Queensland 4222, Australia
}

\begin{abstract}
Climate change is predicted to increase ocean temperatures and alter plankton communities that are food for many marine fishes. To examine the effects of increased sea surface temperature and fluctuating food levels on reef-fish reproduction, breeding pairs of the coral reef damselfish Acanthochromis polyacanthus were maintained for a full summer breeding season in an orthogonal experiment comprising 3 temperature and 2 food levels. Water temperatures were the current-day average summer temperature for the collection location $\left(28.5^{\circ} \mathrm{C}\right)$ and temperatures predicted to become close to the average for this region over the next 50 to $100 \mathrm{yr}\left(30.0\right.$ and $\left.31.5^{\circ} \mathrm{C}\right)$. Pairs were fed either a high or low quantity diet based on average and minimum feeding rates in the wild. Both water temperature and food supply affected reproductive output. Fewer pairs bred at elevated water temperatures and no pairs reproduced at either of the higher temperatures on the lower quantity diet. Furthermore, eggs produced were smaller at 30.0 and $31.5^{\circ} \mathrm{C}$ compared to those at $28.5^{\circ} \mathrm{C}$. Histological analysis of the gonads and steroid hormone measurement did not reveal any apparent differences in patterns of oogenesis among treatments. However, spermatogenesis was reduced at high temperatures despite some increases in plasma androgen levels. Reduced breeding rate at warmer temperatures combined with reduced sperm production indicates the potential for significant declines in A. polyacanthus populations as the ocean warms.
\end{abstract}

KEY WORDS: Climate change $\cdot$ Global warming $\cdot$ Food availability $\cdot$ Reproduction $\cdot$ Growth Resale or republication not permitted without written consent of the publisher

\section{INTRODUCTION}

Climate change is predicted to cause major changes to the ocean environment over the next 50 to $100 \mathrm{yr}$, including significant increases in average sea-surface temperatures and fundamental changes to plankton communities that are the basis of food webs in most marine ecosystems (Guinotte et al. 2003, Hays et al. 2005, Harley et al. 2006, IPCC 2007). While ocean temperature is projected to increase less in tropical locations compared to temperate locations, tropical species might be more sensitive to small temperature increases because they have evolved in a more thermally stable environment (Tewksbury et al. 2008). Most tropical marine species are ectotherms, and small increases in temperature can affect a wide range of traits including physiological condition, growth rate, swimming ability, reproduction and behavior (Houde 1989, Przeslawski et al. 2008, Munday et al. 2009). Several recent studies have shown that increases in ocean temperature consistent with climate change predictions can affect growth rates and aerobic capacity of tropical reef fishes (e.g. Munday et al. 2008a, Nilsson et al. 2009). However, whether temperature increases will affect the reproductive performance of these species is almost completely unknown (Munday et al. 2008b). Reproduction in fishes is only possible within a narrow range of the temperatures that can be tolerated by 
adults (Van Der Kraak \& Pankhurst 1997). Consequently, elevated temperatures could potentially depress reproductive success of tropical reef fishes if populations are already living close to their thermal optima, with potentially serious consequences for population sustainability.

A range of reproductive attributes can be influenced by temperature including the frequency of reproduction (Hilder \& Pankhurst 2003), clutch size and egg size (Brown et al. 2006), embryo development and duration (Taranger \& Hansen 1993, Rombough 1997, Hilder \& Pankhurst 2003), gonad maturation (Davies et al. 1986), and the secretion and action of reproductive hormones (Van Der Kraak \& Pankhurst 1997). To date, most research into the effects of temperature on these reproductive traits has been conducted on temperate and freshwater fishes (exception Hilder \& Pankhurst 2003). Little is known about how any of these traits will be influenced by rising ocean temperatures for tropical marine species (Munday et al. 2008b). It might be predicted, however, that reproduction of tropical marine fishes will be highly sensitive to increasing ocean temperatures because these species have evolved in a relatively stable thermal environment and they experience less seasonal fluctuation in water temperature than do most temperate marine fishes.

For ectotherms such as fish, increasing temperature causes an increase in metabolic rate (Burel et al. 1996, Pörtner \& Knust 2007, Nilsson et al. 2009). Consequently, daily energetic requirements are expected to rise with increasing temperature and individuals will either need to procure more food to maintain currentday growth, maintenance and reproductive functions, or they will need to reduce energy allocation to some activities and functions. The increase in energetic requirements at elevated temperatures creates the potential for trade-offs to occur between various activities (Angilletta et al. 2003). For example, if energy allocation to reproduction is maintained at higher temperature, there might be less energy available for growth. Therefore, predicting the consequences of climate change for most tropical marine fishes depends on understanding the interacting effects of temperature and food supply on life history characteristics and whole-organism function.

In addition to the direct physiological effects of temperature, increased water temperature is predicted to affect the structure of plankton communities that are a food source for many marine fishes (Hays et al. 2005). Changes to plankton communities will not be uniform, but in many locations these communities may become less productive because higher temperatures favor longer, less productive planktonic food-chains (McKinnon et al. 2007) and greater thermal stratification of the water column will reduce nutrient enrichment of the surface layers that is important for planktonic productivity (Poloczanska et al. 2007, Brander 2009). Fish can increase the time spent foraging to enhance their energy intake, however food is usually not in unlimited supply (Buckley et al. 2004). Furthermore, the likelihood of predation also increases with increased foraging time (Biro et al. 2007), which might cause individuals to forage at sub-optimal levels. As a result of likely changes to the productivity of plankton communities, it is important to understand how changes to sea surface temperature will affect individuals depending on different levels of food availability, not just when food is unlimited and easy to access.

This study investigated the independent and interacting effects of water temperature and food availability on reproductive output and body condition of the coral reef fish Acanthochromis polyacanthus. Adult breeding pairs collected from the central Great Barrier Reef, Australia, were maintained at 3 temperature and 2 food levels in a fully orthogonal design.

\section{MATERIALS AND METHODS}

Study species and collection. The tropical damselfish Acanthochromis polyacanthus was used in the present study because it is amenable to laboratory breeding. A. polyacanthus form breeding pairs, with most reproduction on the Great Barrier Reef occurring over a 4 mo period from October to February (Robertson 1973). Eggs are laid on substrate within caves (Thresher 1983) and care is provided to the benthic eggs by both parents (Pankhurst et al. 1999). After hatching, the young remain with the parents for up to 45 d (Kavanagh 2000).

Adult pairs of Acanthochromis polyacanthus were collected in June and July 2007 (austral winter) from a number of locations in the Palm Island region of the central Great Barrier Reef. Fish were collected from Orpheus Island $\left(18^{\circ} 37^{\prime} \mathrm{S}, 146^{\circ} 30^{\prime} \mathrm{E}\right)$, Fantome Island $\left(18^{\circ} 41^{\prime} \mathrm{S}, 146^{\circ} 31^{\prime} \mathrm{E}\right)$, Pelorus Island $\left(18^{\circ} 33^{\prime} \mathrm{S}\right.$, $\left.146^{\circ} 29^{\prime} \mathrm{E}\right)$, and Bramble Reef $\left(18^{\circ} 24^{\prime} \mathrm{S}, 146^{\circ} 42^{\prime} \mathrm{E}\right)$. Care was taken to collect only established breeding pairs, which were identified by the behavioral interaction of individuals towards each other and defense of a common territory. Pairs were collected using a barrier net and hand nets. The standard length of each fish was recorded on collection. These fish were supplemented with breeding pairs collected the previous year from Orpheus Island, making a total of 42 adult pairs. Supplementary pairs represented only 5 of the 42 pairs employed in the experiment. However, to verify that differences did not exist between these 2 groups, the values obtained for supplemented individuals were compared to the means $\pm 1 \mathrm{SE}$ of all non-sup- 
plemented pairs in their treatment group. In all cases the values for the 5 pairs fell within the specified range. Pairs were established in separate $60 \mathrm{l}$ aquariums inside an environmentally-controlled aquarium room at James Cook University (Townsville, Australia). Each aquarium was supplied with a continuous flow of filtered, aerated seawater. A large shelter composed of half a terracotta pot and 2 bricks underneath to elevate it was placed in each aquarium. The age of adult fish was determined at the conclusion of the experiment by counting annual rings from the sagittal otolith (Fowler 1990). Individuals were 2 to 8 yr old (mean $\pm \mathrm{SE}=4.5 \pm$ $0.14 \mathrm{yr}$ ) and there was no significant difference in average age between treatments (factorial ANOVA temperature: $F_{2,65}=0.126, \mathrm{p}=0.882$; food: $F_{1,65}=0.671, \mathrm{p}=$ 0.416 ; temp $\times$ food: $F_{2,65}=0.044, \mathrm{p}=0.957$ ). Age was tested against all reproductive characteristics and was found to not relate significantly. Trends in these characteristics were best described by their relationship to temperature and food.

Experimental design. Adult pairs were kept at the average winter ocean temperature for the Palm Island region until 6 August 2007. Predictions for increases in water temperature on the Great Barrier Reef range from 1 to $3^{\circ} \mathrm{C}$ in the next century (Lough 2007). On 6 August 2007 water temperature was slowly raised over a $2 \mathrm{wk}$ period in $2 / 3$ of the aquariums to split the pairs into 3 treatment groups: (1) average sea water temperature for Palm Island region, (2) $1.5^{\circ} \mathrm{C}$ higher than average, and (3) $3.0^{\circ} \mathrm{C}$ higher than the average for the Palm Island region. The water temperature in each treatment group was subsequently raised every week until the average summer water temperature for the region $\left(28.5^{\circ} \mathrm{C}\right)$ was attained in the lowest temperature treatment (Fig. 1). This resulted in temperature treatments of $28.5^{\circ} \mathrm{C}( \pm 0.05 \mathrm{SE})$ for current day, $30.0^{\circ} \mathrm{C}$ $( \pm 0.05 \mathrm{SE})$ for an increase of 1.5 and $31.5^{\circ} \mathrm{C}( \pm 0.06 \mathrm{SE})$ for an increase of $3.0^{\circ} \mathrm{C}$. Weekly increases in water temperature were matched to the $10 \mathrm{yr}$ average increase in water temperatures during spring in the Palm Island region. Fish were kept in their treatment groups until 28 March 2008 when the experiment was concluded. The geographic range of Acanthochromis polyacanthus is from $15^{\circ} \mathrm{N}-26^{\circ} \mathrm{S}$ and $116^{\circ} \mathrm{E}-169^{\circ} \mathrm{E}$, which encompasses an average summer temperature range of approximately 27 to $31^{\circ} \mathrm{C}$. Similar temperature ranges will be experienced by many other broadly distributed coral reef fish (Munday et al. 2008b). Day length was controlled with artificial lighting and adjusted weekly to match the natural cycle for the central Great Barrier Reef.

Breeding pairs at each temperature were randomly assigned to 2 feeding treatments (high or low ration) to produce a fully orthogonal design with 6 to 8 breeding pairs at each combination of temperature and food ration. The high food treatment consisted of $0.376 \mathrm{~g}$ Aquaculture Nutrition NRD 12/20 pellets ind. $\mathrm{d}^{-1}(1.0 \%$ body weight, protein $55 \%$, fat $9 \%$, fiber $1.9 \%$ ), and the low treatment of $0.188 \mathrm{~g}$ ind. $\mathrm{d}^{-1}(0.5 \%$ body weight, i.e. half the high ration). The above feeding levels were validated in a natural setting in the Palm Island region by observing the activity level of breeding pairs throughout the day, and subsequent collection and measurement of gut fullness in the late afternoon. It was found that fish consumed from 0.7 to $2.6 \%$ (average: $1.47 \%$ ) of their body weight per day. This average amount of plankton would convert to approximately 4.37 calories and the lower range would be 2.15 calories (Clarke \& Bishop 1948). In addition, it was determined that fish spent $30 \%$ of their time on average on vigorous activities other than feeding, such as territorial defense. Therefore, the experimental feeding levels were adjusted to be 0.5 and $1.0 \%$ to account for the lack of time fish in the experiment would spend on these activities in an aquarium situation, as well as the enhanced energy content of formulated diet.

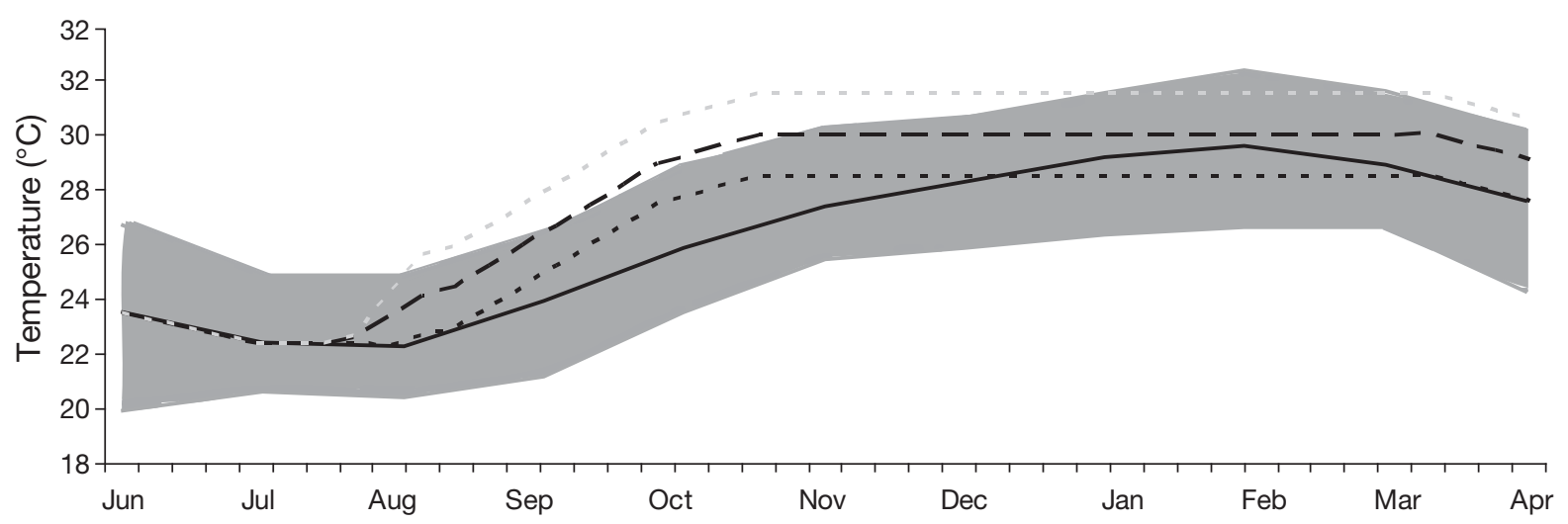

Fig. 1. Seasonal water temperature at the Palm Island Region. Solid black line: mean temperature; grey shaded area: temperature range; black dotted line: current day temperature; black dashed line: current day $+1.5^{\circ} \mathrm{C}_{\text {; }}$ grey dotted line: current day $+3.0^{\circ} \mathrm{C}$ 
Reproductive output. Nesting sites were checked daily at 09:00 $\mathrm{h}$ for the presence of eggs. An underwater photograph was taken of each first clutch for estimation of the number of eggs laid. To measure egg size, a sample of 15 eggs (representing 2 to $6 \%$ of a clutch) was collected from random locations within each clutch using tweezers. Eggs were photographed under a stereomicroscope directly after removal from the clutch. Egg area was estimated from the photographs using Optimas 6.5 software (Media Cybernetics). The number of eggs in each clutch at laying was estimated by viewing the digital photograph on a computer screen using Image Tool (UTHSCSA). To approximate the reproductive output of each spawning, the number of eggs in each clutch was multiplied by the average egg area of the 15 sample eggs for that clutch. Nest sites were checked daily to determine the period (d) from laying to hatching (embryonic duration).

Growth and body condition. Temperature, food supply and reproductive output can all influence energy available for growth and maintenance activities; we therefore compared growth rates and fat deposits between temperature and food treatments. Estimating growth and fat reserves among treatments also enabled us to determine whether reduced reproduction at elevated temperatures and low food rations could be due to energy shortages in these treatments. To determine growth, standard length (to the nearest $0.5 \mathrm{~mm}$ ) and wet weight (to the nearest $0.01 \mathrm{~g}$ ) was measured for each fish following euthanasia. Fat within the stomach region (visceral fat) was quantified to investigate differences in the amount of stored energy in fish from different temperature and food treatments. The gut was dissected from the body cavity and immediately frozen. Subsequently, all visible fat deposits were carefully removed from the external surfaces of the stomach with tweezers and weighed to the nearest $1 \mathrm{mg}$.

Gamete production and hormones. To investigate if water temperature and food supply affected gonadal steroidogenesis, blood samples were taken from each fish at the end of the experiment to estimate levels of the steroid hormones $17 \beta$-estradiol $\left(E_{2}\right)$, testosterone (T) in females, and $\mathrm{T}, 11$-ketotestosterone (11KT) in males based on their demonstrated roles in female and male reproduction respectively (Pankhurst et al. 1999). Each fish was caught with a large hand net and a blood sample taken by caudal puncture using preheparinized syringes within 2 min of capture. Blood was immediately stored on ice and then placed in a refrigerator and centrifuged within $5 \mathrm{~h}$. Blood plasma was then frozen at $-80^{\circ} \mathrm{C}$ until steroid measurement. Plasma samples were extracted with ethyl acetate and resuspended in assay buffer; plasma levels of $\mathrm{E}_{2}, \mathrm{~T}$ and
$11 \mathrm{KT}$ were determined by radioimmunoassay as described in Pankhurst et al. 1999. Extraction efficiency was determined by recovery of ${ }^{3} \mathrm{H}$-labelled steroid from replicates of a plasma pool and was 71.6, 65.2 , and $83.6 \%$ for $\mathrm{T}, \mathrm{E}_{2}$ and $11 \mathrm{KT}$ respectively. Assay values were corrected accordingly. All samples were measured in a single assay for each steroid.

Finally, the gonads of euthanazed fish were fixed in $4 \%$ formaldehyde, $5 \%$ acetic acid, and $1.3 \%$ calcium chloride (FAACC) for 2 mo. Gonads were then embedded in paraffin wax, sectioned longitudinally at $5 \mu \mathrm{m}$, and stained with Mayer's alum haematoxylin and Young's eosin-erythrosine. Proportions of mature, vitellogenic oocytes (in ovaries) and spermatozoa (in testis) were estimated by scoring the presence of vitellogenic follicles or spermatozoa at intervals along a transect (40 and $21 \mu \mathrm{m}$ intervals for ovary and testis respectively); transects ran along the longest dimension of a representative longitudinal section from the gonad of each fish. A longitudinal section was used to account for a variation in gamete production between the posterior and anterior parts of the gonad.

Data analysis. Reproductive characteristics: Due to a lack of breeding in 2 temperature and food combinations ( 30.0 and $31.5^{\circ} \mathrm{C}$ with low food rations), 2 separate analyses were used to compare each of the other reproductive characteristics (egg area, clutch size and reproductive output) among temperatures and between food ration. Clutch size was compared among temperatures with a Kruskal-Wallis test due to data not satisfying ANOVA assumptions, and was then compared between high and low food rations at $28.5^{\circ} \mathrm{C}$ using a $t$-test. Egg area and reproductive output was compared among temperatures with ANOVA and then with a $t$-test between food levels. Reproductive output data was log transformed to improve normality of distribution prior to analysis. Significant main effects in ANOVA were examined using Fisher's least significant difference (LSD) post hoc analysis. A Kruskal-Wallis test was used to compare embryo duration between treatments. All analyses were completed with Statistica 8.0 (StatSoft).

Growth and body condition: Growth is often correlated with initial length in fishes. Therefore, to account for variation in growth that could be attributed to variation in initial length of fish within treatments, ANCOVA was used to compare growth during the experiment depending on the initial length of each fish. Temperature and food levels were regarded as fixed factors, growth $(\mathrm{mm})$ was the dependent variable and initial standard length $(\mathrm{mm})$ was the covariate. Fisher's LSD post hoc analysis was used to compare means where significant treatment effects were identified.

Differences between fat deposits depending on temperature and food treatments were also tested with 
ANCOVA. Temperature and food levels were regarded as fixed factors, fat (mg) was the dependent variable and final standard length $(\mathrm{mm})$ was the covariate.

Gonadal condition and plasma steroid levels: The proportion of spermatozoa in male gonads and the proportion of vitellogenic oocytes in female gonads were arc sin transformed prior to statistical analysis to meet the assumptions of ANOVA. Their relationship (depending on treatment) was tested with a factorial ANOVA (temperature and food fixed factors) followed by Fisher's LSD post hoc analysis.

Plasma levels of $\mathrm{T}$ and $\mathrm{E}_{2}$ in females were square root transformed, and $11 \mathrm{KT}$ levels in males were log transformed, prior to analysis. Hormone levels were compared among temperature and food treatments using factorial ANOVA. Fisher's LSD post hoc analysis was used to compare means where significant treatment effects were identified.

\section{RESULTS}

\section{Reproductive characteristics}

Temperature and food ration both affected the number of pairs that reproduced, with no pairs reproducing at elevated temperatures and low ration (Table 1). Seven of 8 pairs at $28.5^{\circ} \mathrm{C}$ on the high-ration diet produced egg clutches. In contrast, on the high ration diet, only 3 of 8 pairs reproduced at $30.0^{\circ} \mathrm{C}$ and 3 of 7 pairs at $31.5^{\circ} \mathrm{C}$; no pairs reproduced at these temperatures on the low ration diet. Despite the obvious reductions in the proportion of pairs that reproduced at higher temperatures, there was no difference in the timing of breeding, with fish at all temperatures laying egg clutches within 3 wk of each other.

Egg size declined at higher temperatures (Fig 2a; ANOVA: $F_{2,10}=6.27, \mathrm{p}=0.017$ ). In contrast, food ration did not significantly affect egg size at $28.5^{\circ} \mathrm{C}$ (Fig $2 \mathrm{a}$; $t=0.514, \mathrm{df}=8, \mathrm{n}=10, \mathrm{p}=0.621$ ). Although clutch size exhibited a declining trend with increasing tempera-

Table 1. Acanthochromis polyacanthus. Effect of temperature and food availability on the number of pairs that spawned

\begin{tabular}{|lcc|}
\hline Food level & Temp. $\left({ }^{\circ} \mathrm{C}\right)$ & No. of pairs \\
\hline High & 28.3 & 7 \\
& 30.0 & 3 \\
\multirow{2}{*}{ Low } & 31.5 & 3 \\
& 28.3 & 3 \\
& 30.0 & 0 \\
& 31.5 & 0 \\
\hline
\end{tabular}
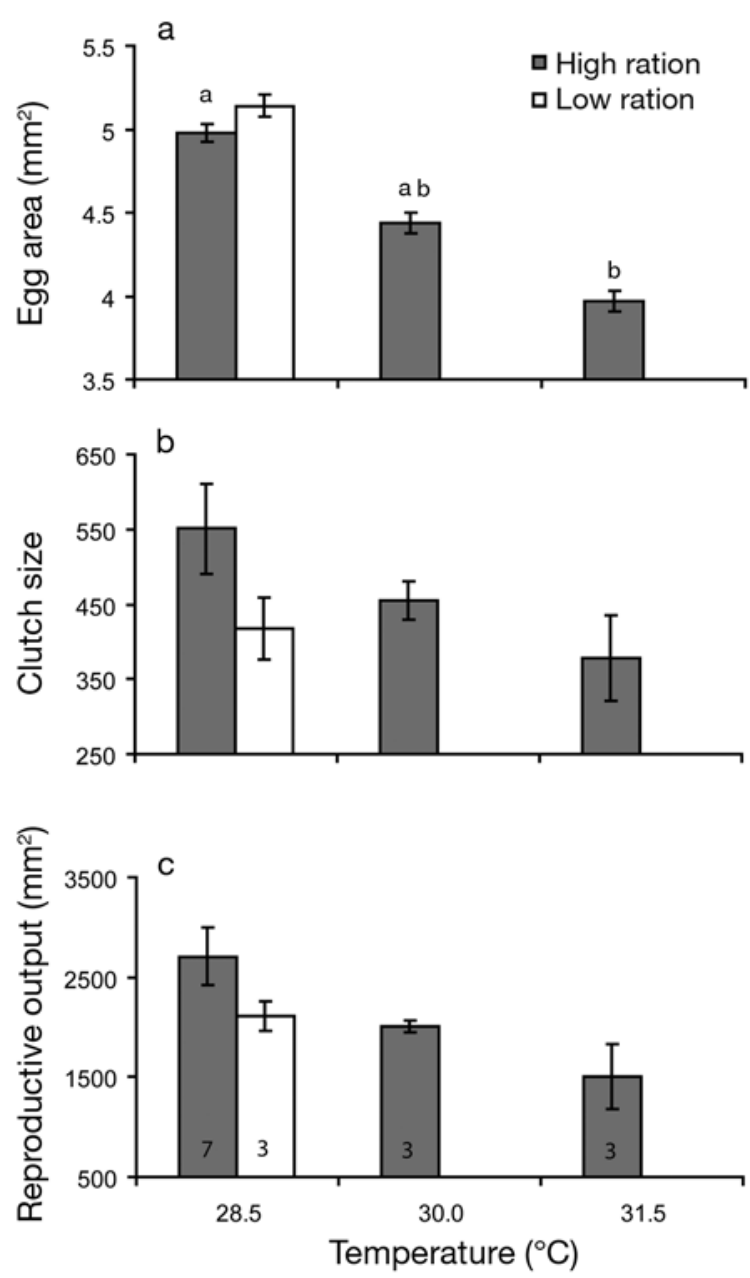

Fig. 2. Acanthochromis polyacanthus. Mean (a) egg area, (b) clutch size and (c) reproductive output (mean egg area $x$ clutch size) in relation to temperature and ration level. Values are mean \pm SE. Numbers within bars are replicates and letters represent differences between temperatures within the high food level $(p<0.05)$

ture and a reduction in food availability (Fig. 2b), neither were found to be statistically significant (Kruskal-Wallis temperature: $\chi^{2}=4.569$, df $=2, \mathrm{p}=$ 0.102 ; food: $t=1.908, \mathrm{df}=8, \mathrm{n}=10, \mathrm{p}=0.332$ ). Reproductive output, which combines both egg size and the number of eggs produced, exhibited a decrease with increasing temperature that was not statistically significant (Fig 2c; $F_{2,10}=4.01, \mathrm{p}=0.055$ ). There was no significant difference in reproductive output between food treatments at $28.5^{\circ} \mathrm{C}($ Fig $2 \mathrm{c} ; t=1.29, \mathrm{df}=8, \mathrm{n}=$ $10, \mathrm{p}=0.232$ ).

Embryonic duration also decreased with increasing temperature. Specifically a $3.0^{\circ} \mathrm{C}$ rise in water temperature caused a reduction of approximately $1.5 \mathrm{~d}$ in embryonic duration (mean at $28.5^{\circ} \mathrm{C}: 10.33 \pm 0.17 \mathrm{~d}$; at $31.5^{\circ} \mathrm{C}: 9 \pm 0.00 \mathrm{~d}$; Kruskal-Wallis: $\chi^{2}=3.343, \mathrm{df}=2, \mathrm{n}=$ $13, \mathrm{p}=0.03)$. Food availability did not significantly 
affect embryo duration at $28.5^{\circ} \mathrm{C}$ (mean for high ration: $10.43 \pm 0.20 \mathrm{~d}$; for low ration: $10 \pm 0.00 \mathrm{~d}$ ).

\section{Growth and body condition}

There was no difference in the standard length ( $\mathrm{mm})$ of fish among treatments at the start of the experiment (ANOVA temperature: $F_{2,78}=1.854, \mathrm{p}=0.163$; food: $F_{1,78}=1.403, \mathrm{p}=0.240$; temperature $\times$ food: $F_{2,78}=$ $1.374, \mathrm{p}=0.259)$. Growth rate declined with increasing temperature (Fig. 3 ; ANCOVA: $F_{2,58}=4.10, \mathrm{p}=0.010$ ) and with reduced food availability (ANCOVA: $F_{1,58}=$ 14.38, p < 0.001). Growth was greatest for fish in the current day temperature on the high food ration (Fig. 3), but declined rapidly with increasing water temperature and decreased food supply. Post-hoc tests showed that differences in growth between food levels were significant at 28.5 and $30.0^{\circ} \mathrm{C}$, but not at $31.5^{\circ} \mathrm{C}$.

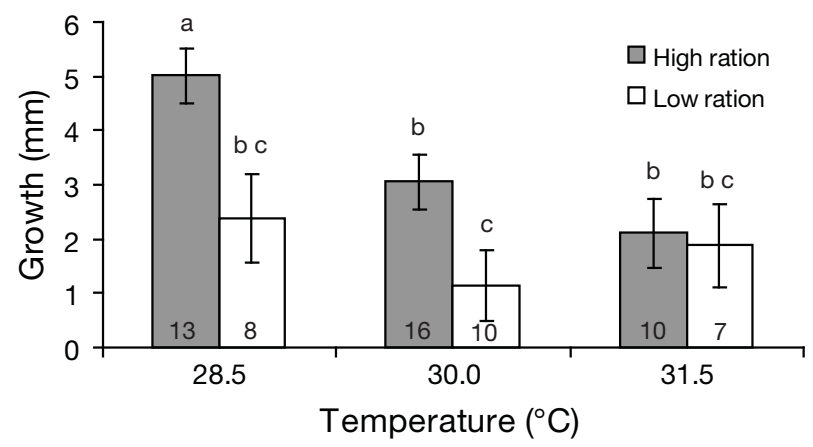

Fig. 3. Acanthochromis polyacanthus. Mean growth $( \pm \mathrm{SE})$ at different temperature and ration levels during the experimental period after correction for the relationship between growth and initial length. Numbers within bars are replicates and letters represent differences between all treatments $(p<0.05)$

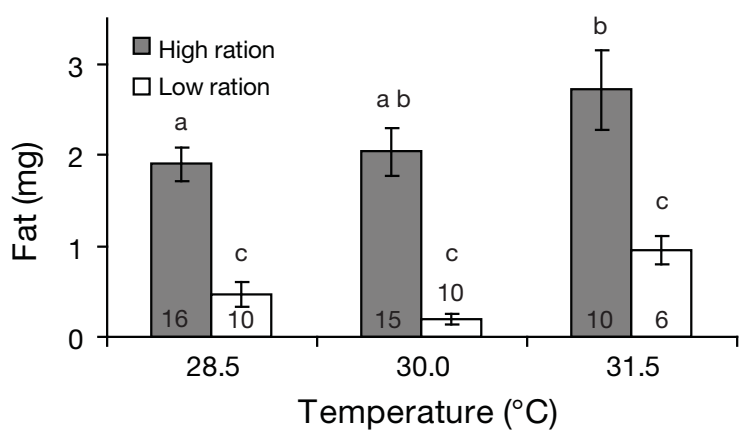

Fig. 4. Acanthochromis polyacanthus. Mean weight of visceral fat $( \pm \mathrm{SE})$ at different temperature and ration levels during the experimental period after correction for the relationship between growth and initial length. Numbers within bars are replicates and letters represent differences between all treatments $(\mathrm{p}<0.05)$
Growth rate also depended on the initial length of fish (ANCOVA: $F_{1,58}=27.29, \mathrm{p}<0.001$ ).

The amount of visceral fat in the body cavity was substantially greater in fish given the high ration diet, regardless of temperature (Fig. 4 ; ANCOVA: $F_{1,67}=$ 38.99, $\mathrm{p}<0.001$ ). While not as distinct, visceral fat also increased significantly with temperature (ANCOVA: $F_{2,67}=3.96, p=0.024$ ), indicating that reduced reproduction at the high temperatures was not primarily due to poor nutritional condition. The amount of visceral fat also depended on initial length (ANCOVA: $F_{1,67}=6.55$, $\mathrm{p}=0.013)$.

\section{Gonadal condition and plasma steroid levels}

The proportion of spermatozoa in testes differed among temperatures and food rations (Fig. 5; factorial ANOVA temperature: $F_{2,28}=12.001, \mathrm{p}<0.001$; temperature $\times$ food: $F_{2,28}=4.118, \mathrm{p}=0.027$ ). The proportion of spermatozoa decreased with increasing water temperature, but the response was greater on the low food ration compared to the high food ration. At $31.5^{\circ} \mathrm{C}$, males on the low food ration had fewer spermatozoa than males on the high ration; however, in both other temperatures low ration fish always had more spermatozoa.

The proportion of vitellogenic stage oocytes in ovaries was also significantly related to temperature (factorial ANOVA: $F_{2,28}=6.453, \mathrm{p}=0.005$ ). However, this effect was due to the ovaries of 3 fish having very few vitellogenic oocytes in the low ration group at $30.0^{\circ} \mathrm{C}$. The mean proportion of vitellogenic oocytes in ovaries for this group (35\%) was significantly different from all other groups (mean $>64 \%$ ) ( $p<0.02$ for all combinations).

In females, plasma levels of $\mathrm{T}$ and $\mathrm{E}_{2}$ did not differ between temperatures or food ration (Table 2; factorial

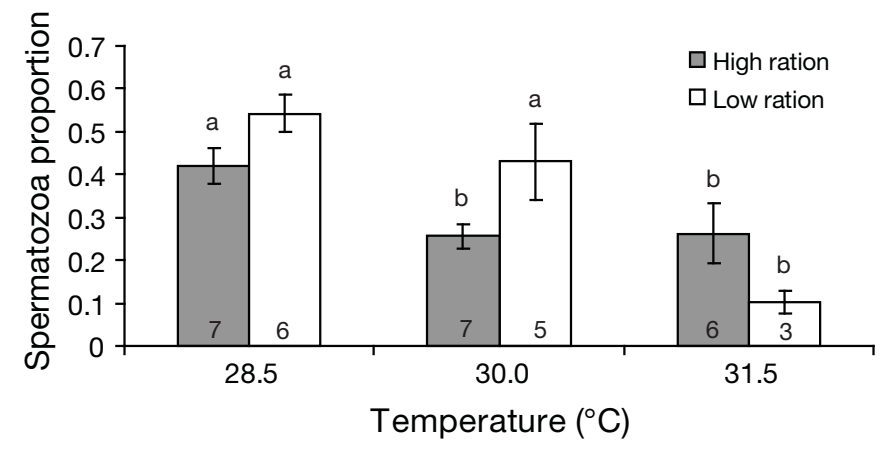

Fig. 5. Acanthochromis polyacanthus. Mean proportion of spermatozoa in male gonads $( \pm \mathrm{SE})$ between temperature and ration levels. Numbers within bars are replicates and letters represent differences between all treatments $(p<0.05)$ 
Table 2. Acanthochromis polyacanthus. Effect of temperature and ration on plasma levels of testosterone $(\mathrm{T})$ and 17ßestradiol $\left(\mathrm{E}_{2}\right)$. Values are mean $\pm \mathrm{SE}$

\begin{tabular}{|lcccr|}
\hline $\begin{array}{c}\text { Food } \\
\text { level }\end{array}$ & $\begin{array}{c}\text { Temp. } \\
\left({ }^{\circ} \mathrm{C}\right)\end{array}$ & $\begin{array}{c}\text { Male } \\
\mathrm{T}\end{array}$ & $\begin{array}{c}\text { Female } \\
\mathrm{T}\end{array}$ & $\mathrm{E}_{2}$ \\
\hline High & 28.5 & $1.74 \pm 0.16$ & $2.40 \pm 0.28$ & $1.73 \pm 0.32$ \\
& 30.0 & $2.93 \pm 0.52$ & $2.58 \pm 0.58$ & $1.81 \pm 0.91$ \\
& 31.5 & $3.00 \pm 0.51$ & $3.74 \pm 0.88$ & $1.82 \pm 0.43$ \\
Low & 28.5 & $2.74 \pm 0.47$ & $2.54 \pm 0.25$ & $1.61 \pm 0.58$ \\
& 30.0 & $2.00 \pm 0.40$ & $2.13 \pm 0.18$ & $3.27 \pm 1.21$ \\
& 31.5 & $3.16 \pm 0.92$ & $3.96 \pm 1.65$ & $1.9 \pm 1.45$ \\
\hline
\end{tabular}

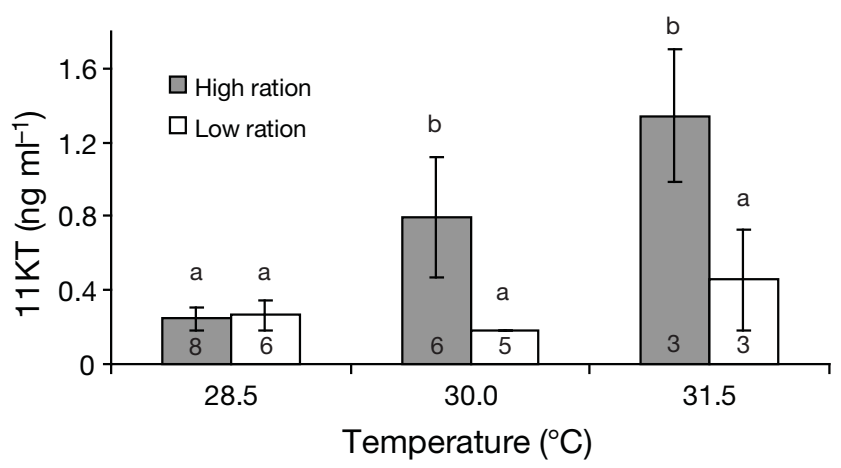

Fig. 6. Acanthochromis polyacanthus. Effect of temperature and ration level on plasma levels of 11-ketotestosterone $(11 \mathrm{KT})$ in males $( \pm \mathrm{SE})$. Numbers within bars are replicates and letters represent differences between all treatments $(\mathrm{p}<0.05)$

ANOVA T temperature: $F_{2,26}=2.606, \mathrm{p}=0.930$; food: $F_{2,26}=0.097, \mathrm{p}=0.758 ; \mathrm{E}_{2}$ temperature: $F_{2,26}=0.487$, $\mathrm{p}=0.620$; food: $\left.F_{2,26}=0.954, \mathrm{p}=0.338\right)$. In contrast, plasma levels of $11 \mathrm{KT}$ in males were affected by both temperature and food availability (Fig. 6; factorial ANOVA temperature: $F_{2,25}=5.412, \mathrm{p}=0.011$; food: $F_{1,25}=8.372, \mathrm{p}=0.008$ ), and levels of testosterone were affected by an interaction between temperature and food ration (Table 2 ; temperature $\times$ food: $F_{2,27}=3.425$, $\mathrm{p}=0.047$ ). Increasing plasma levels of $11 \mathrm{KT}$ were seen with increasing temperature (Fig. 6), but only in the high food treatments. Post-hoc tests showed that there was no significant differences in $11 \mathrm{KT}$ levels between high and low ration fish at the lowest temperature, but that there were significant differences at both 30.0 and $31.5^{\circ} \mathrm{C}$. Post-hoc tests showed that the significant interaction of temperature and food on testosterone level was due to (1) $28.5^{\circ} \mathrm{C}$ fish on high food ration having lower testosterone levels than $28.5^{\circ} \mathrm{C}$ fish on low ration, and (2) $28.5^{\circ} \mathrm{C}$ fish on high food ration having lower testosterone levels than 30.0 and $31.5^{\circ} \mathrm{C}$ fish on high ration (Table $2, \mathrm{p}<0.05$ ).

\section{DISCUSSION}

Climate change is predicted to increase average water temperature and affect food supply for marine fishes, but how these changes will influence reproductive performance is still poorly understood. We found that both temperature and food level had substantial effects on some reproductive attributes and physical condition of a common reef fish, Acanthochromis polyacanthus. Most noticeably, increases in water temperature caused a substantial reduction in reproduction, with complete reproductive failure at elevated temperatures and low food supply. Fish that reproduced at higher temperatures produced smaller eggs, which has important implications for juvenile success (Donelson et al. 2008). There was no indication of plasticity in the timing of reproduction relative to water temperature, with individuals at all temperatures commencing breeding within a week of each other. Although the lack of breeding in some pairs may represent a delay in reproduction, and thus some plasticity in this trait, the loss of a season's breeding in a population with average ages of 2 to 8 yr would represent a significant loss of individual fitness. Given the apparent lack of plasticity in the timing of reproduction, the present results suggest that reproductive failures and declines in $A$. polyacanthus populations are likely to occur as the ocean warms.

Populations might adapt to increasing temperature over many generations or acclimate within a generation over multiple years, but the potential for this to occur in species such as Acanthochromis polyacanthus is currently unknown (Munday et al. 2008b). A few investigations of acclimation or adaptation potential on a time scale necessary for climate change have been completed (see Angilletta 2009), however none involve tropical marine fishes. In most cases observed adaptation took from 21 to 432 generations allowing for epigenetic pathways to assist in the process, but in one instance adaptation was observed within only 2 generations (Van Doorslaer et al. 2007). Understanding the acclimation and adaptation potential for reef species is vital for predicting the long term effects of climate change.

Elevated water temperature and low ration resulted in cessation of reproduction in the present study. Even when a greater amount of food was available reproductive capacity was still diminished, with fewer pairs breeding than at lower temperatures. The presence of similar amounts of visceral fat in fish on the high ration diet at all temperatures suggests that daily energetic requirements might still have being met at higher temperatures. Consequently, it appears that elevated water temperature alone can affect reproductive success and could result in reduced reproductive capacity 
of tropical reef fish regardless of food availability. There is limited information on the combined effects of temperature and food availability on reproduction in ectothermic vertebrates, but studies on invertebrates show similar trends to those observed here, with egg production suppressed at high temperatures even when ample food was provided (Woodward \& White 1981, Snell 1986, Lee et al. 2003).

Exposure of Acanthochromis polyacanthus in the present study to elevated temperatures produced significant reductions in egg size. Egg size is a useful indicator of current reproductive condition, and a predictor of subsequent larval success. Smaller eggs are often produced by fish in poorer physical condition (Marteinsdottir \& Steinarsson 1998, Donelson et al. 2008), and smaller eggs usually produce smaller or poorer conditioned offspring (Green 2008). Furthermore, the quality of larvae and juveniles are known to affect the risk of mortality, with smaller and poorer conditioned individuals often being selected against (Hoey \& McCormick 2004, Grorud-Colvert \& Sponaugle 2007, McCormick \& Meekan 2007). Consequently, it is possible that a smaller proportion of progeny produced by fish at warmer temperatures would ultimately survive.

The reduced growth rate of adults at warmer temperatures also has important implications for reproductive performance. Increased size of reproductively active individuals is known to beneficially affect many components of reproduction including fecundity (Morita \& Takashima 1998, Lambert et al. 2000), egg size (Vallin \& Nissling 2000, Johnston \& Legget 2002) and offspring size (Tamada \& Iwata 2005). In consequence, a reduction in growth rate resulting from ocean warming could result in fish producing fewer offspring and progeny of reduced fitness. It was expected in the present study that adults might exhibit a trade-off between reproduction and growth; however, both attributes diminished with increasing temperature suggesting that such a trade-off did not occur. Instead, a trade-off may have existed between reproduction and growth versus energy stores, which may have been conserved for future reproduction. Additionally, visceral fat is not the only location of stored energy within a fish (Cowey \& Sargent 1972); therefore investigation of muscle protein and liver lipids may have emphasized or altered the current picture.

Elevated water temperature had effects on both plasma steroid levels and gamete production in male fish in the present study. The reduction in spermatozoa observed in this experiment could indicate a possibility for reduced fertilization success as water temperatures increase. However, no direct measurements of fertilization capacity were made in the present study, so the possible effects on fertility are not known. Levels of the gonad steroid $11 \mathrm{KT}$ increased with temperature, but only in the presence of high food availability. Levels of $11 \mathrm{KT}$ in Acanthochromis polyacanthus increase with reproductive maturity and in relation to recent or imminent spawning events (Pankhurst et al. 1999). The failure to maintain elevated $11 \mathrm{KT}$ at high temperature and low ration in the present study is consistent with the hypothesis that elevated $11 \mathrm{KT}$ is required to maintain reproductive function in males. More significant inhibitory effects have been seen in other species, where increasing temperatures were reported to reduce both plasma $\mathrm{T}$ and 11KT levels in vivo in male rainbow trout (Manning \& Kime 1985). This was consistent with studies in other species showing increased levels of steroid inactivation by conjugation at high temperature (Kime 1979). A similar effect to that seen in the present study was described for male carp Cyprinus carpio; increased levels of $11 \mathrm{KT}$ were produced at high temperatures, but increased levels of the conjugate T-glucuronide were also produced (Kime \& Manning 1986). However, not all effects of elevated temperature appear to be generated by increasing rates of conjugation. Males of the red sea bream Pagrus major showed decreased mRNA levels of the enzyme 11ß-hydroxylase (which mediates the conversion of $\mathrm{T}$ to $11 \mathrm{KT}$ ) in association with reduced spermatogenesis after $8 \mathrm{wk}$ exposure to temperatures of $20^{\circ} \mathrm{C}$ and above (Lim et al. 2003).

The proportion of mature oocytes in the gonad and the level of reproductive hormones of females did not exhibit a strong relationship with temperature or food treatments. However, the observed reduction in egg size suggests that exposure to elevated temperatures did have an effect on vitellogenesis in the present study. Reductions in final egg size in thermally stressed fish have been reported in rainbow trout (Pankhurst \& Thomas 1998) and Atlantic salmon Salmo salar (King et al. 2003). This was associated with reductions in plasma $\mathrm{E}_{2}$ levels, and levels of the yolk precursor vitellogenin (in turn synthesized by the liver in response to stimulation by $E_{2}$ ) in Atlantic salmon, but no change in plasma $E_{2}$ in rainbow trout (Pankhurst et al. 1996, Pankhurst \& Thomas 1998). Later studies on Atlantic salmon showed that depression of $E_{2}$ levels for only part of the period of vitellogenesis could generate reductions in plasma vitellogenin, egg size and subsequent fertility and survival (King et al. 2007). It is possible that the same effect has occurred here but has not been detected using only single time point sampling. Effects to eggs may also have occurred through modification of biochemical components, which can affect a range of egg and progeny attributes (Brooks et al. 1997), however this was not explicitly tested in the present study.

There was evidence in the present study of a partial protective effect of nutritional condition on reproduc- 
tive processes at higher temperature, as some pairs were still reproductively active. The basis for this effect is not known, but data from field studies suggest that the effect is exercised through the endocrine system. Assessment of reproductive condition of Acanthochromis polyacanthus from reef sites, covering a range of habitats and fish densities, showed that lowest reproductive output was associated with sites of high overall fish density and consequently the highest competition for access to plankton crossing the reef (Pankhurst et al. 2008). In vitro incubation of ovarian follicles from these sites showed impaired steroidogenesis with, in particular, reduced production of $E_{2}$. This could be partially restored by treatment with an analogue of luteinizing hormone (LH), suggesting that fish from high density sites had suppressed pituitary release of LH. The same effect may be operating in the present study among fish on the low ration.

The results of the present study are generally consistent with the trend of decreasing reproduction with increasing temperature in a range of species (Van Der Kraak \& Pankhurst 1997). However, an additional factor here is the relatively small temperature increase required to produce negative effects in tropical fish. The difference between lower and upper thresholds for reproduction in salmonids is typically 12 to $14^{\circ} \mathrm{C}$ (Taranger \& Hansen 1993, Pankhurst et al. 1996, King $\&$ Pankhurst 2000), whereas in the present study there was a reduction in the number of reproductively active pairs with an increase of as little as $1.5^{\circ} \mathrm{C}$. A lower temperature threshold for reproductive activity in Acanthochromis polyacanthus has been established at 24 to $25^{\circ} \mathrm{C}$ (Hilder \& Pankhurst 2003), and on the basis of the present study an upper limit of 30 to $31^{\circ} \mathrm{C}$ under optimal feeding conditions. In combination it suggests a maximum range of $7^{\circ} \mathrm{C}$ for this species. If this trend is consistent, the implication for tropical systems in comparison to temperate is that smaller directional shifts in ocean temperature may be required to produce inhibitory effects on stages of reproduction.

We found that temperatures 1.5 to $3.0^{\circ} \mathrm{C}$ higher than the current summer average significantly influenced reproduction and growth of adult Acanthochromis polyacanthus. When temperatures were elevated, and only a low level of food was available, reproduction ceased. Even when a greater amount of food was supplied fewer pairs reproduced, and there was a marked reduction in egg size at higher temperature. This might result in reduced spawning at elevated temperatures, with associated declines in population size. Alternatively, ocean warming may shift the seasonality of reproduction in A. polyacanthus and other species. The capacity of populations to adjust to warmer conditions will depend partially on the level of seasonal change in the system, and how close current seasonal minima and maxima are to temperature thresholds for inhibitory effects. Studies on the potential for longterm acclimation or adaptation of reproductive traits to increased temperature are logistically difficult, but should be a priority for future research given the significant effects detected here.

Acknowledgements. Thanks to T. Coop, D. Dixson, M. Gagliano, L. Gonzalez Reynoso, M. Malerba, J. Moore, B. Murphy and all the staff at JCU Aquarium Research Facility. Funding was provided by the ARC Centre of Excellence, CSIRO Climate Adaptation Flagship and the GBRMPA Science for Management Awards. This project was completed under JCU Ethics A1233.

\section{LITERATURE CITED}

Angilletta MJ Jr (2009) Thermal adaptation: a theoretical and empirical synthesis. Oxford University Press, New York

Angilletta MJ Jr, Wilson RS, Navas CA, James RS (2003) Tradeoffs and the evolution of thermal reaction norms. Trends Ecol Evol 18:234-240

Biro PA, Post JR, Booth DJ (2007) Mechanisms for climateinduced mortality of fish populations in whole lake experiments. Proc Natl Acad Sci USA 104:9715-9719

> Brander K (2009) Impacts of climate change on fisheries. J Mar Syst 79:389-402

Brooks S, Tyler CR, Sumpeter JP (1997) Egg quality in fish: what makes a good egg? Rev Fish Biol Fish 7:387-416

Brown NP, Shields RJ, Bromage NR (2006) The influence of water temperature on spawning patterns and egg quality in the Atlantic halibut (Hippoglossus hippoglossus L.). Aquaculture 261:993-1002

Buckley LJ, Caldarone EM, Lough RG (2004) Optimum temperature and food-limited growth of larval Atlantic cod (Gadus morhua) and haddock (Melanogrammus aeglefinus) on Georges Bank. Fish Oceanogr 13:134-140

> Burel C, Person-Le Ruyet J, Gaumet F, Le Roux A, Sévère A, Boeuf G (1996) Effects of temperature on growth and metabolism in juvenile turbot. J Fish Biol 49:678-692

Clarke GL, Bishop DW (1948) The nutritional value of marine zooplankton with a consideration of its use as an emergency food. Ecology 29:54-71

Cowey CB, Sargent JR (1972) Fish nutrition. In: Russell FS, Yonge $M$ (eds) Advances in marine biology, Vol 10. Academic Press, London, p 383-492

> Davies PR, Hanyu I, Furukawa K, Nomura M (1986) Effect of temperature and photoperiod on sexual maturation and spawning of the common carp. Induction of spawning by manipulating photoperiod and temperature. Aquaculture 52:137-144

> Donelson JM, McCormick MI, Munday PL (2008) Parental condition affects early life-history of a coral reef fish. J Exp Mar Biol Ecol 360:109-116

Fowler AJ (1990) Validation of annual growth increments in the otoliths of a small, tropical coral reef fish. Mar Ecol Prog Ser 64:25-38

> Green BS (2008) Maternal effects in fish populations. Adv Mar Biol 54:1-105

> Grorud-Colvert K, Sponaugle S (2006) Influence of condition on behavior and survival potential of a newly settled coral reef fish, the bluehead wrasse Thalassoma bifasciatum. Mar Ecol Prog Ser 327:279-288

Guinotte JM, Buddemeier RW, Kleypas JA (2003) Future coral 
reef habitat marginality: temporal and spatial effects of climate change in the Pacific basin. Coral Reefs 22: 551-558

Harley CDG, Randall Hughes A, Hultgren KM, Miner BG and others (2006) The impacts of climate change in coastal marine systems. Ecol Lett 9:228-241

Hays GC, Richardson AJ, Robinson C (2005) Climate change and marine plankton. Trends Ecol Evol 20:337-344

Hilder ML, Pankhurst NW (2003) Evidence that temperature change cues reproductive development in the spiny damselfish, Acanthochromis polyacanthus. Environ Biol Fishes 66:187-196

Hoey AS, McCormick MI (2004) Selective predation for low body condition at the larval-juvenile transition of a coral reef fish. Oecologia 139:23-29

Houde ED (1989) Comparative growth, mortality and energetics of marine fish larvae: temperature and implied latitudinal effects. Fish Bull 87:471-495

IPCC (2007) Summary for policymakers. In: Climate change 2007: the physical science basis. Contribution of Working Group I to the Fourth Assessment Report of the Intergovernmental Panel on Climate Change. Cambridge University Press, Cambridge, p 1-18

Johnston TA, Leggett WC (2002) Maternal and environmental size gradients in the egg size of an iteroparous fish. Ecology 83:1777-1791

Kavanagh KD (2000) Larval brooding in the marine damselfish Acanthochromis polyacanthus (Pomacentridae) is correlated with highly divergent morphology, ontogeny and life-history traits. Bull Mar Sci 66:321-337

Kime DE (1979) The effect of temperature on the testicular steroidogenic enzymes of the rainbow trout, Salmo gairdneri. Gen Comp Endocrinol 39:290-296

Kime DE, Manning NJ (1986) Maturational and temperature effects on steroid hormone production by testes of the carp, Cyprinus carpio. Aquaculture 54:49-55

King HR, Pankhurst NW (2000) Ovulation of Tasmanian Atlantic salmon maintained at elevated temperatures: implications of climate change for sustainable industry development. In: Norberg B, Kjesbu OS, Taranger GL, Andersson E, Stefansson SO (eds) Proc 6th Int Symp Reproductive Physiol Fish. John Grieg, Bergen, p 396-398

King HR, Pankhurst NW, Watts M, Pankhurst PM (2003) Effect of elevated summer temperatures on gonadal steroid production, vitellogenesis and egg quality in female Atlantic salmon. J Fish Biol 63:153-167

King HR, Pankhurst NW, Watts M (2007) Reproductive sensitivity to elevated water temperatures in female Atlantic salmon is heightened at certain stages of vitellogenesis. J Fish Biol 70:190-205

Lambert Y, Dutil JD, Ouellet P (2000) Nutritional condition and reproductive success in wild fish populations. In: Norberg B, Kjesbu OS, Taranger GL, Andersson E, Stefansson SO (eds) Proc 6th Int Symp Reproductive Physiol Fish. John Grieg, Bergen, p 77-84

Lee H, Ban S, Ikeda T, Matsuishi T (2003) Effect of temperature on development, growth and reproduction in the marine copepod Pseudocalanus newmani at satiating food condition. J Plankton Res 25:261-271

Lim BS, Kagawa H, Gen K, Okuzawa K (2003) Effects of water temperature on the gonadal development and expression of steroidogenic enzymes in the gonad of juvenile red seabream, Pagrus major. Fish Physiol Biochem 28: 161-162

Lough J (2007) Climate and climate change on the Great Barrier Reef. In: Johnson JE, Marshall PA (eds) Climate change and the Great Barrier Reef: a vulnerability assess- ment. Great Barrier Reef Marine Park Authority, Townsville, p 15-50

> Manning NJ, Kime DE (1985) The effect of temperature on testicular steroid production in the rainbow trout, Salmo gairdneri, in vivo and in vitro. Gen Comp Endocrinol 57: $377-382$

Marteinsdottir G, Steinarsson A (1998) Maternal influence on the size and viability of Iceland cod Gadus morhua eggs and larvae. J Fish Biol 52:1241-1258

McCormick MI, Meekan MG (2007) Social facilitation of selective mortality. Ecology 88:1562-1570

McKinnon AD, Richardson AJ, Burford ME, Furnas MJ (2007) Vulnerability of Great Barrier Reef plankton to climate change. In: Johnson JE, Marshall PA (eds) Climate change and the Great Barrier Reef: a vulnerability assesment. Great Barrier Reef Marine Park Authority, Townsville, p 121-152

> Morita K, Takashima Y (1998) Effect of female size on fecundity and egg size in white-spotted charr: comparison between sea-run and resident forms. J Fish Biol 53: 1140-1142

> Munday PL, Kingsford MJ, O'Callaghan M, Donelson JM (2008a) Elevated temperature restricts growth potential of the coral reef fish Acanthochromis polyacanthus. Coral Reefs 27:927-931

Munday PL, Jones GP, Pratchett MS, Williams AJ (2008b) Climate change and the future for coral reef fishes. Fish Fish 9:261-285

Munday PL, Leis JM, Lough JM, Paris CB, Kingsford MJ, Berumen ML, Lambrechts J (2009) Climate change and coral reef connectivity. Coral Reefs 28:379-395

> Nilsson GE, Crawley N, Lunde IG, Munday PI (2009) Elevated temperature reduces the respiratory scope of coral reef fishes. Glob Change Biol 15:1405-1412

Pankhurst NW, Thomas PM (1998) Maintenance at elevated temperature delays the steroidogenic and ovulatory responsiveness of rainbow trout Oncorhynchus mykiss to luteinizing hormone releasing hormone analogue. Aquaculture 166:163-177

Pankhurst NW, Purser GJ, Van Der Kraak G, Thomas PM, Forteath GNR (1996) Effect of holding temperature on ovulation, egg fertility, plasma levels or reproductive hormones and in vitro ovarian steroidogenesis in the rainbow trout Oncorhynchus mykiss. Aquaculture 146:277-290

> Pankhurst NW, Hilder PI, Pankhurst PM (1999) Reproductive condition and behavior in relation to plasma levels of gonadal steroids in the spiny damselfish Acanthochromis polyacanthus. Gen Comp Endocrinol 115:53-69

Pankhurst NW, Fitzgibbon QP, Pankhurst PM, King HR (2008) Habitat-related variation in reproductive endocrine condition in the coral reef damselfish Acanthochromis polyacanthus. Gen Comp Endocrinol 155:386-397

Poloczanska ES, Babcock RC, Butler A, Hobday A and others (2007) Climate change and Australian marine life. Oceanogr Mar Biol Annu Rev 45:407-478

Pörtner HO, Knust R (2007) Climate change affects marine fishes through the oxygen limitation of thermal tolerance. Science 315:95-97

> Przeslawski R, Ahyong S, Byrne M, Wörheides G, Hutchings $P$ (2008) Beyond corals and fish: the effects of climate change on noncoral benthic invertebrates of tropical reefs. Glob Change Biol 14:2773-2795

> Robertson DR (1973) Field observations on the reproductive behavior of a pomacentrid fish Acanthochromis polyacanthus. Z Tierpsychol 32:319-324

Rombough PJ (1997) The effects of temperature on embryonic and larval development. In: Wood CM, McDonald DG 
(eds) Global warming: implications for freshwater and marine fish. Cambridge University Press, Cambridge, p $177-223$

Snell TW (1986) Effects of temperature, salinity and food level on sexual and asexual reproduction in Brachionus plicatilis (Rotifera). Mar Biol 92:157-162

Tamada K, Iwata K (2005) Intra-specific variations of egg size, clutch size and larval survival related to maternal size in amphidromous Rhinogobius goby. Environ Biol Fishes 73: 379-389

Taranger GL, Hansen T (1993) Ovulation and egg survival following exposure to Atlantic salmon, Salmo salar L., broodstock to different water temperatures. Aquacult Fish Manag 24:151-156

Tewksbury JJ, Huey RB, Deutsch CA (2008) Putting heat on tropical animals. Science 320:1296-1297

Thresher RE (1983) Habitat effects on reproductive success in the coral reef fish Acanthochromis polyacanthus Poma-

Editorial responsibility: Gretchen Hofmann,

Santa Barbara, California, USA centridae. Ecology 64:1184-1199

Vallin L, Nissling N (2000) Maternal effects on egg size and egg buoyancy of Baltic cod, Gadus morhua: implications for stock structure effects on recruitment. Fish Res 49: 21-37

Van Der Kraak G, Pankhurst NW (1997) Temperature effects on the reproductive performance of fish. In: Wood CM, McDonald DG (eds) Global warming: implications for freshwater and marine fish. Cambridge University Press, Cambridge, p 159-176

Van Doorslaer WV, Stoks R, Jeppesen E, De Meester L (2007) Adaptive microevolutionary responses to simulated global warming in Simocephalus vetulus: a mesocosm study. Glob Change Biol 13:878-886

Woodward IO, White RWG (1981) Effects of temperature and food on the fecundity and egg development rates of Boeckella symmetvica Sars (Copepoda: Calanoida). Aust J Mar Freshw Res 32:997-1002

Submitted: April 8, 2009; Accepted: October 9, 2009 Proofs received from author(s): February 9, 2010 